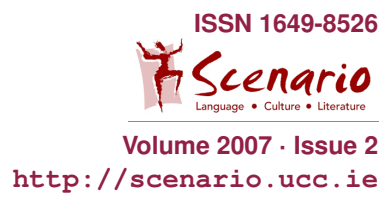

TaT - Texts around Theatre - TaT

\title{
The Stage by the Sea
}

\section{Christoph Ransmayr}

\begin{abstract}
Contemporary Austrian author Christoph Ransmayr takes us to a place on the South Irish coast where, amidst beautiful nature, there is music and dance under the open skies, and staging is accomplished with the simplest means. There, active participation in performing arts is experienced as a natural and integral component of everyday existence; it lightens personal loads and supports the coastal inhabitants' courage to face life.
\end{abstract}

\section{The Stage by the Sea}

The stage that I speak of is to be found high above the cliffs of the Southern Irish Atlantic coast on one of those innumerable roads, lined by stone walls, gorse and fuchsia hedges, that lose their way in bays cutting deep into the coast and craggy ranges of hills between the lighthouses of Galley Head and Ireland's most south-western promontory, Mizen Head. A stage so near the surf that all the actors, singers or poets who ever stepped onto it had to raise their voices to sing or simply roar louder than the sea. My friend Eamon from Skibbereen, who had also shown me how to anchor a boat safely between cliffs or lay out lobster pots or release vicious dogfish caught in the pots without getting injured, my friend Eamon brought me on a stormy February day to this stage, located miles away from the nearest settlement. The crossroads where it lies is called Glaisín Álainn in southern Irish Gaelic. That means Lovely Meadow.

Until very recently and on six days of the week, Glaisín Álainn actually was a mere pasture with a splendid view of the sea, a meadow that sloped gently down to the rocky coast and where the solitary ruin of a stone house, formerly occupied by a man called Liam O'Shea, still stood. Until the year when O'Shea emigrated to Western Australia he had lived in Glaisín Álainn with his two cows, four sheepdogs, a donkey and a varying number of sheep, secretly distilling poteen, a potato whisky, in the shaft of the abandoned copper-mines at Roaring Water Bay, riding on his donkey-cart after such poteen-making evenings, often asleep, through the villages, or singing to the accompaniment of a button-accordion an almost endless ballad with all the names, dates and 
number of victims of more than a hundred shipwrecks on the west coast of Ireland. With all of his delivery trips, which were spread out over several weeks and during which he would be told the latest news from the villages and the nearby islands, would pass them on, and in addition transport bottles of beer, tobacco, caramel and other resellable treats to Glaisín Álainn, he always seemed to be preparing solely for that evening when his house would become an arena, a theatre, and his meadow a place of festivity.

For on Sunday evenings on Glaisín Álainn there gathered farmers, fishermen, beachcombers, turf-cutters, artisans and the Irish servants of English manorhouses, an audience that travelled for hours by foot or at best on their bikes from the farmsteads and hamlets of West Cork to take part here in something which under less modest circumstances and in less stormy places is called performing arts: what dancing there was at Liam O'Shea's! Dancing, singing, the telling of stories and recitation of ballads to the tune of the button-accordion or tin-whistle, and all that under the open skies on a stage that Liam O'Shea had built in the middle of his meadow from sea-sand and stones worn smooth by the tides and which his audience simply called the platform.

On Liam O'Shea's platform on Sunday evenings every member of the audience could transform themselves into a wildly acclaimed performer, anyone who had just been listening in sadness or amusement could rise, reach for the accordion or tin whistle and begin to play or sing to the applause of singers and musicians about to lapse into attentive silence.

And even if the wind and the crash of the surf only allowed for musical instruments such as the button-accordion and tin-whistle, goatskin drums and the uillean pipes, a mellow and melancholy sounding variety of the bagpipes - when Liam O'Shea played the accordion and sang of shipwrecks and the godsend of flotsam and jetsam, of pigs dancing on the breakers, of hundreds of bales of snow-white cotton drifting up Bantry Bay like ice-floes, of swimming carpets of oranges, boxes full of clocks and brass bells and silver bars that had lost their glitter and of the gold of Spanish frigates, then his audience thought that they heard not only a button-accordion but occasionally a fiddle as well, or even the Irish harp itself and other chords that were otherwise too soft for the tumultuous reality of Glaisín Álainn and therefore of little use.

O'Shea's stone stage had no roof, not a single wall that might shelter it from wind and rain, no curtain, no flight of steps. Hardly raised above the pasture surrounding it, performers could step onto it simply by clambering over gorse and grass, and with this one stride could leave a whole world behind them: they entered into a melody, a ballad, a burst of applause or laughter in which their lives suddenly seemed new and different, transfigured into chords and words. This did not make their life any easier, but at least it became a story that could be told and understood - and, in some songs of mockery and struggle, perhaps even changed.

From:

Christoph Ransmayr, Die Dritte Luft oder Eine Bühne am Meer.

(C) S.Fischer Verlag GmbH, Frankfurt am Main 1997, 8 - 11 
Translated by Eoin Bourke 